\title{
HUBUNGAN VARIASI MENGAJAR GURU DENGAN HASIL BELAJAR SISWA DI KELAS V SDN 105401 NAMO LINTING KECAMATAN STM HULU SUMATERA UTARA
}

\author{
Srie Faizah Lisnasari, ${ }^{1)}$ Eninta Br Barus ${ }^{2)}$ \\ 1) Dosen Universitas Quality Medan \\ Email : sriefaizah2502@gmail.com
}

\begin{abstract}
ABSTRAK
Tujuan penelitian ini adalah untuk mengetahui hubungan variasi mengajar guru terhadap hasil belajar siswa pada mata pelajaran IPA.

Penelitian ini dilaksanakan di SDN 105401 Namo Linting Kecamatan Sibolangit (Sumatera Utara) Tahun Ajaran 2018/2019.Jenis penelitian adalah korelasional dengan metode deskriptif kuantitatif. Sampel dalam penelitian ini adalah seluruh siswa kelas V yang berjumlah 24 orang.Pengumpulan data penelitian dilakukan dengan menggunakan angket berisi pertanyaan tentang variasi mengajar guru $(\mathrm{X})$ dan hasil belajar siswa (Y).menggunakan hasil ujian tengah semester. Teknik analisis data dengan menggunakan statistik korelasi product moment dan uji-t.

Hasil penelitian menunjukkan bahwa variasi mengajar guru tergolong baik dengan skor rata-rata 77,38 dengan standar deviasi sebesar 9,01 walaupun masih adavariasi mengajar guru yang skornya di bawah rata-rata. Hasil belajar IPA siswa tergolong baik dengan nilai terendah60, dan nilai tertinggi adalah 90 dengan rata-rata 77,42 dan Standar Deviasi 10,53. Dari hasil pengujian hipotesis diperoleh nilai yaitu $\mathrm{r}_{\text {hitung }}$ $0,8638>\mathrm{r}_{\text {tabel }} 0329$, dan $\mathrm{t}_{\text {hitung }} 8,04>\mathrm{t}_{\text {tabel }} 2,0739$. Hal ini menunjukkan bahwa ada hubungan yang positif dan signifikan antara variasi mengajar guru dengan hasil belajar siswa.

Dengan demikian, dapat disimpulkan bahwa ada Hubungan Variasi Mengajar Guru dengan Hasil Belajar Siswa Pada Mata Pelajaran IPA di Kelas V SDN 105401 Namo Linting Tahun Ajaran 2018/2019
\end{abstract}

Kata kunci: Variasi mengajar, Hasil Belajar, IPA.

\section{PENDAHULUAN}

Tujuan pendidikan di Indonesia adalah untuk mencerdaskan kehidupan bangsa. Hal ini dapat tercapai apabila manusianya berilmu, cakap, kreatif, mandiri, dan menjadi warga negara yang demokratis serta bertanggung jawab. Tercapainya tujuan tersebut dapat dilakukan melalui pendidikan formal di sekolah. Salah satu faktor yang mempengaruhinya adalah unsur guru. Guru sangat besar peranannya dalam upaya mencerdaskan kehidupan bangsa. Sehingga guru dipersyaratkan harus memiliki 4 kompetensi yaitu kompetensi profesional, individual, sosial dan pedagogik. Dalam kompetensi Pedagogik, guru harus memiliki keterampilan dalam mengajar. Salah satu keterampilan mengajar guru adalah terampil dalam melakukan variasi mengajar. Hal ini penting karena tanpa variasi mengajar, siswa malah akan cepat merasa bosan dalam menerima pelajaran sehingga aspek yang akan dikembangkan pada diri siswa yakni aspek kognitif, afektif dan psikomoriknya tidak akan tercapai secara optimal.

Berdasarkan hasil pendataan nilai hasil belajar IPA dari 24 orang siswa kelas V pada semester Ganjil TA 2018/2019 ditemukan bahwa 15 orang $(62,5 \%)$ sudah tuntas belajar sedangkan 9 orang lagi $(37,5 \%)$ belum tuntas. Hal ini belum memenuhi standar ketuntasan klasikal yakni $85 \%$. Berdasarkan uraian maka penulis tertarik untukmelakukan penelitian 
dengan judul Hubungan variasi mengajar guru dengan hasil belajar siswa pada mata pelajaran IPA di kelas V SDN 105401 Namo Linting Tahun Ajaran 2018/2019.

\section{METODE PENELITIAN}

Penelitian ini dilaksanakan di SDN 105401 yang berlokasi di Desa Namo Linting Kec.STM HuluSumatera Utara pada Semester Genap Tahun Ajaran 2018/2019. Penyebaran angket dilakukan pada tanggal 26 Maret 2019.

Populasi dalam penelitian ini adalah seluruh siswa kelas V SDN 105401 Namo Linting yang berjumlah 24 siswa. Sampel yang digunakan adalah sampel total yaitu siswa kelas V SDN 105401 Namo Linting yang berjumlah 24 orang.

Jenis penelitian ini adalah penelitian deskriptif korelasional.Menjelaskan hubungan antara variabel-variabel, yaitu variasi mengajar guru sebagai variabel bebas (X) dan hasil belajar siswa sebagai variabel terikat $(\mathrm{Y})$.

Instrumen yang digunakan dalam penelitian ini adakah angket dan daftar kumpulan nilai hasil belajar siswa yang diperoleh dari sekolah tempat penelitian. Angket yang digunakan divalidasi terlebih dahulu sebelum digunakan.Angket yang dikembangkan dalam penelitian ini terdiri atas pernyataan-pernyataan yang berkaitan dengan definisi operasional variable $\mathrm{X}$, dan dokumentasi yang digunakan dalam penelitian ini berkaitan dengan definisi operasional variabel $\mathrm{Y}$.

Untuk mengetahui variasi mengajar guru di kelas V SDN 105401 Namo Linting dilakukan dengan menggunakan angket, pernyataan angket yang valid berjumlah 27 pernyataan. Untuk mengetahui hasil belajar IPA siswa di kelas V SDN 105401 Namo Linting dilakukan menggunakan hasil ujian Mid Semester Genap Tahun Ajaran 2018/2019.Dengan demikian informasi yang diperoleh tersebut diharapkan dapat memberikan gambaran, keterangan dan fakta yang akurat mengenai suatu kondisi tertentu.Angket adalah sejumlah daftar pertanyaan tertulis yang digunakan untuk memperoleh informasi dari responden.Angket disusun berdasarkan kisi-kisi dari setiap variabel dengan menggunakan skala Likert.

Menurut sugiyono (2016:93), "Skala Likert digunakan untuk mengukur sikap, pendapat dan persepsi seseorang atau sekelompok orang tentang fenomena sosial".Skala likert adalah skala yang yang disusun dimana responden diminta untuk memberikan tanda ceklist pada salah satu dari 4 kemungkinan jawaban yang tersedia. Dimana setiap jawaban masing-masing akan diberi skor sebagai berikut:

- SL (selalu ) dengan skala nilai 4

- SR (sering ) dengan skala nilai 3

- JR ( jarang ) dengan skala nilai 2

- TP (tidak pernah ) dengan skala nilai 1

Dari setiap jawaban akan diperoleh jumlah nilai yang akan disajikan dalam bentuk tabel dan selanjutnya data tersebut akan dianalisis melalui perhitungan perhitungan statistik. 
Tabel 1. Kisi-kisi Angket

\begin{tabular}{|c|c|c|c|c|}
\hline Variabel & Indikator & Deskriptor & $\begin{array}{c}\text { Nomor } \\
\text { soal }\end{array}$ & $\begin{array}{c}\text { Jumlah } \\
\text { item }\end{array}$ \\
\hline \multirow[t]{6}{*}{$\begin{array}{l}\text { Variasi } \\
\text { Mengajar } \\
\text { Guru }\end{array}$} & $\begin{array}{l}\text { 1.Penggunaan } \\
\text { variasi suara }\end{array}$ & $\begin{array}{l}\text { Suara guru dapat bervariasi dalam } \\
\text { intonasi yang cepat atau lambat, volume } \\
\text { keras atau lembut, dari suara yang } \\
\text { gembira berubah menjadi sedih. }\end{array}$ & $\begin{array}{c}1,2,3,4,5 \\
, 6\end{array}$ & 6 \\
\hline & $\begin{array}{l}\text { 2.Pemusatan } \\
\text { perhatian } \\
\text { siswa }\end{array}$ & $\begin{array}{l}\text { Pemusatan perhatian siswa pada hal-hal } \\
\text { yang dianggap penting. Misalnya } \\
\text { dengan mengatakan "Perhatikan baik- } \\
\text { baik", atau "Nah ini penting sekali". }\end{array}$ & $\begin{array}{c}8,9,10,1 \\
1,12\end{array}$ & 5 \\
\hline & $\begin{array}{l}\text { 3.Kesenyapan } \\
\text { atau kebisuan } \\
\text { guru }\end{array}$ & $\begin{array}{l}\text { Kesenyapan atau selingan diam yang } \\
\text { tiba-tiba atau disengaja guru saat } \\
\text { menerangkan sesuatu untuk menarik } \\
\text { perhatian siswa. }\end{array}$ & 13,14 & 2 \\
\hline & $\begin{array}{l}\text { 4.Mengadakan } \\
\text { kontak } \\
\text { pandang }\end{array}$ & $\begin{array}{l}\text { Bila guru sedang bebicara atau } \\
\text { berinteraksi dengan siswa, sebaiknya } \\
\text { pandangan menjelajahi seluruh kelas } \\
\text { dan melihat ke mata murid-murid untuk } \\
\text { menunjukkan adanya hubungan yang } \\
\text { intim. }\end{array}$ & $15,16,17$ & 3 \\
\hline & $\begin{array}{l}\text { 5.Gerakan badan } \\
\text { dan mimic }\end{array}$ & $\begin{array}{l}\text { Variasi dalam ekspresi wajah guru } \\
\text { (tersenyum, mengerut dahi, cemberut, } \\
\text { menaikkan alis mata, menunjukkan } \\
\text { kagum, tercengang atau heran), variasi } \\
\text { dalam gerakan kepala (menganggukkan, } \\
\text { mengeleng, mengangkat atau } \\
\text { merendahkan kepala), variasi gerak } \\
\text { badan (menunjukkan jari atau } \\
\text { menjentikkan jari untuk menarik } \\
\text { perhatian murid). }\end{array}$ & $\begin{array}{l}18,19,21 \\
22,23\end{array}$ & 5 \\
\hline & $\begin{array}{l}\text { 6.Pergantian } \\
\text { posisi dan } \\
\text { gerak guru di } \\
\text { dalam kelas }\end{array}$ & $\begin{array}{l}\text { Perpindahan posisi dapat dilakukan dari } \\
\text { depan ke bagian belakang, dari sisi kiri } \\
\text { ke sisi kanan, atau diantara anak didik } \\
\text { dari belakang ke samping anak didik. }\end{array}$ & $\begin{array}{l}25,26,27 \\
, 28,29,3 \\
0\end{array}$ & 6 \\
\hline
\end{tabular}

\section{HASIL PENELITIAN DAN PEMBAHASAN}

Data variasi mengajar guru diperoleh dari angket variasi mengajar guru dengan empat pilihan jawaban yang sebelumnya telah diuji validitas dan realibilitasnya.. Selanjutnya penelitian melakukan pengkategorian data variasi mengajar guru yang dilakukan di SDN 105401 Namo Linting Kecamatan STM Hulu.Hasil pengambilan data dengan angket kemudian dianalisis dan dihitung jumlah skornya. Skor yang terendah 65 dan skor yang tertinggi 95, dengan rata-rata 77,38 sedangkan Standar Deviasi $\quad 9,01$. 


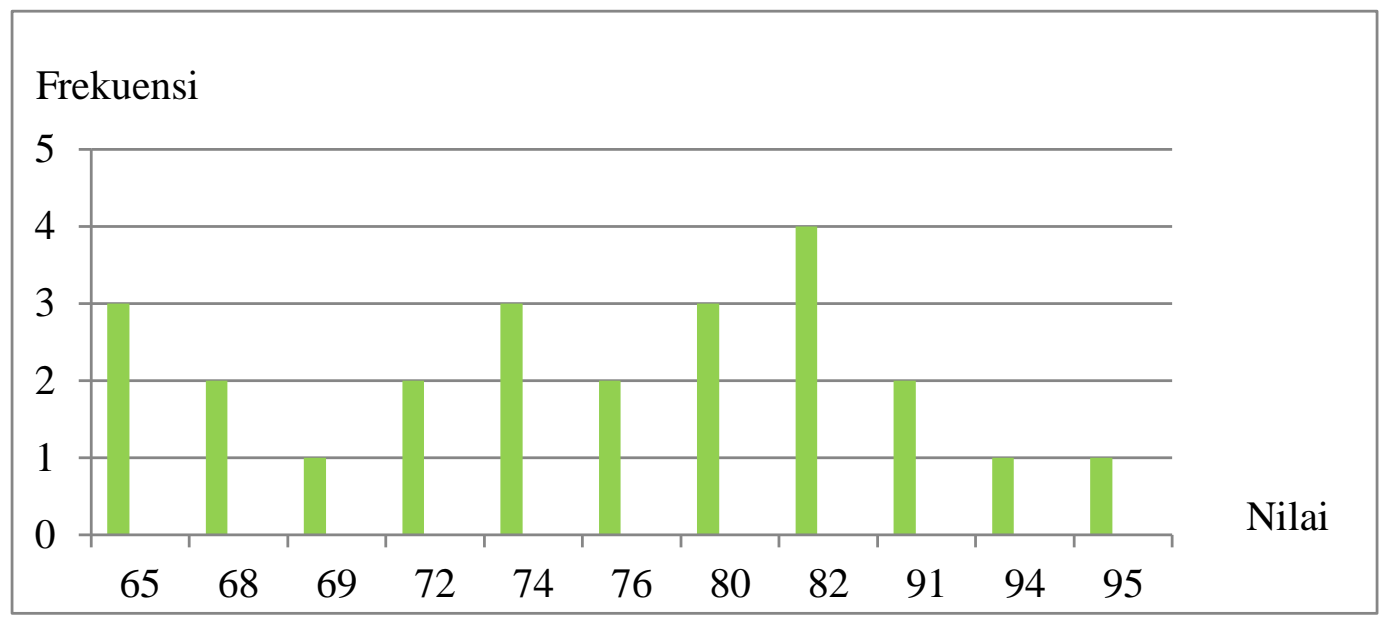

Gambar 1 :Diagram Batang Variasi Mengajar Guru di Kelas V SDN 105401 Namo Linting Kecamatan STM Hulu.

Data mengenai hasil belajar IPA siswa diperoleh dari hasil data teknik dokumentasi.Dokumentasi yang digunakan yaitu nilai hasil ujian Mid Semester, semester genap Tahun Ajaran 2018/2019. Nilai ujian mid semester genap Tahun Ajaran 2018/2019 di kelas V SDN 105401 Namo Linting memiliki rentan nilai dari 0 sampai 100 . Berdasarkan data, diperoleh nilai terendah untuk hasil belajar IPA adalah 60 sedangkan nilai tertingginya adalah 90 dengan ratarata 77,42 dan standar deviasi 10,53. Sehingga dapat disimpulkan hasil belajar siswa di sekolah termasuk kedalam kategori cukup. Hal tersebut dapat diketahui pada gambar 2 diagram batang hasil belajar ujian Mid Semester IPA Semester Genap kelas V SDN 105401 Namo Linting Tahun Ajaran 2018/2019 sebagai berikut: Seperti tersaji dalam Gambar 2

\section{Pengujian Hipotesis}

Pengujian untuk mengetahui hubungan variabel variasi mengajar guru dan hasil belajar siswa SDN 105401 Namo Linting digunakan analisis korelasi product moment, sedangkan untuk menguji keberartiannya digunakan uji t. Berikut adalah hasil perhitungan yang diperoleh: Tabel 2

Tabel 2. Korelasi Variabel dan Uji Hipotesis

\begin{tabular}{|c|c|c|c|c|}
\hline Korelasi & $\mathrm{r}_{\text {hitung }}$ & $\mathrm{r}_{\text {tabel }}$ & $\mathrm{t}_{\text {hitung }}$ & $\mathrm{t}_{\text {tabel }}$ \\
\hline $\mathrm{r}_{\mathrm{xy}}$ & 0,8638 & 0,329 & 8,040 & 2,0739 \\
\hline
\end{tabular}

Koefisien korelasi variasi megajar guru dengan hasil belajar siswa kelas V SDN 105401 Namo Linting sebesar 0,8638 dan $\mathrm{r}_{\text {tabel }}$ dengan signifikasi 0,05 adalah 0,329 , maka $r_{\text {hitung }}>r_{\text {tabel }}$, hal ini menunjukkan adanya hubungan yang positif antara variasi mengajar guru dengan hasil belajar siswa pada mata pelajaran IPA di kelas V SDN
105401 Namo Linting Tahun Ajaran 2018/2019. 


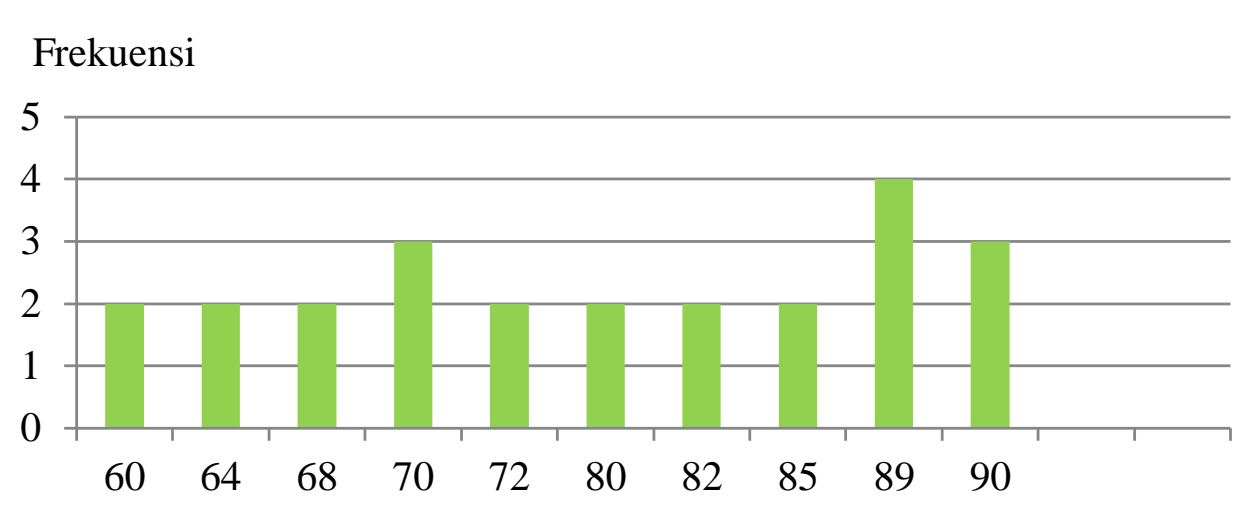

\section{Gambar 2: Hasil Nilai IPA Ujian Tengah Semester}

Selanjutnya dilakukan uji $\mathrm{t}$ (keberartian hubungan). Dari tabel, hasil $t_{\text {hitung adalah 8,040 sedangkan }}$ $t_{\text {tabel }}$ dengan signifikasi 0,05 adalah 2,073 , maka $t_{\text {hitung }}>t_{\text {tabel }}$ hal ini menunjukkan bahwa terdapat hubungan yang cukup berarti antara variasi mengajar guru dengan hasil belajar siswa kelas V SDN 105401 Namo Linting Tahun Ajaran 2018/2019.

Dengan demikian, maka dapat disimpulkan bahwa adanya hubungan positif yang signifikan antara variasi mengajar guru dengan hasil belajar siswa pada mata pelajaran IPA di kelas IV SDN 105401 Namo Linting Tahun Ajaran 2018/2019 dapat diterima kebenarannya.

\section{Pembahasan Hasil Penelitian}

Dari hasil analisisdata yang dikumpulkan melalui angket diperoleh skor terendah 65 dan skor tertinggi 95 dengan rata-rata 77,38. Kemudian data hasil belajar siswa (nilai ujian Mid Semester) pada mata pelajaran IPA diperoleh nilai terendah 60 dan nilai tertinggi 90 dengan rata-rata 77,42.

Regresi antara angket variasi mengajar dengan hasil belajar siswa, menghasilkan nilai konstanta $\mathrm{a}=$ 6,54 dan nilai $b=1,13$ sehingga persamaan regresinya adalah $\hat{\mathrm{Y}}=$ $6,54+1,13 \mathrm{X}$. Nilai $\mathrm{b}$ bertanda positif, berarti variasi mengajar berpengaruh secara positif terhadap hasil belajar siswa.

Berdasarkan uji hipotesis diperoleh $t_{\text {hitung }}=8,0404 \mathrm{dan} t_{\text {tabel }}=2,073$ dimana $8,0404>2,073$. Hal ini menunjukkan hubungan yang signifikan antara variasi mengajar guru dengan hasil belajar IPA.

Proses belajar siswa dipengaruhi dari 2 faktor yaitu faktor dari dalam dirinya (internal) maupun dari luar dirinya (eksternal). Proses belajar ini juga sangat mempengaruhi hasil belajar yang akan diperoleh oleh siswa. Salah satu faktor luar diri siswa yang mempengaruhi proses adalah aspek guru. Bagaimana guru berkompeten dalam mengajar. Kompetensi guru yang perlu dikembangkan adalah kompetensi pribadi, profesional, sosial dan pedagogik. Kompetensi guru dalam mengajar termasuk antara lain seperti kompetensi variasi mengajar termasuk ke dalam kompetensi Pedagogik yang harus terus dikembangkan terus menerus, sebab hal ini dapat mempengaruhi semangat, motivasi, antusias siswa dalam belajar. Hal ini akan berdmpak kepada hasil belajarnya.Seperti yang dikatakan Ahmad Sabri( 2010:94), Variasi adalah suatu kegiatan guru dalam mengenal konteks interaksi belajar mengajar yang ditujukan untuk mengatasi kebosanan murid sehingga, dalam situasi belajar mengajar, murid senantiasa menunjukkan ketekunan, antusiasme, 
serta penuh partisipasi. Sejalan dengan pendapat Syaiful Bahri \& Djamrah (2014:160). Variasi ini pada dasarnya meliputi variasi suara, variasi gerakan, anggota badan, dan variasi perpindahan posisi guru dalam kelas.Bagi siswa, variasi tersebut dilihat sebagai sesuatu energik, antusias, bersemangat, dan semuanya memiliki relevansi dengan hasil belajar.

\section{SIMPULAN}

Simpulan penelitian ini adalah:.

1. Variasi mengajar guru di kelas V SDN 105401 Namo Linting Kec. STM Hulu nilai rata-rata total 77,38.

2. Hasil belajar siswa kelas V SDN 105401 Namo Linting Kec. STM Hulu nilai rata-rata total 77,42 .

3. Ada hubungan yang signifikan antara variasi mengajar guru dengan hasil belajar IPA siswa kelas V SDN 105401 Namo Linting Kec. STM Hulu Tahun Ajaran 2018/2019.

\section{DAFTAR PUSTAKA}

Amiruddin. 2016. Perencanaan Pembelajaran. Yogyakarta : Parama Ilmu

Arifin, Zainal.2016. Evaluasi Pembelajaran. Bandung: Remaja RosdaKarya

Suharsimi Arikunto.2014.Prosedur Penelitian. Jakarta: Rineka Cipta.

Djamrah.Syaiful Bahri \& Aswan Zain. 2014. Strategi Belajar Mengajar. Jakarta: Rineka Cipta.

Halimah, Leli. 2017. Keterampilan Mengajar. Bandung : PT Refika Aditama.

Hamdayama ， Jumanta.2016. Metodologi Pengajaran. Jakarta: Bumi Aksara.
Haryono.2013. Pembelajaran IPA. Yogyakarta: Amara Books

Istarani dan pulungan , Intan.2014.Ensiklopedi

Pendidikan. Medan: Media Persada.

Khairani.2013. Psikologi Belajar. Yogyakarta: Aswaja Pressindo

Ngalimun, 2017.Strategi Pembelajaran. Yogyakarta: Parama Ilmu.

Oemar,Hamalik.2014:140. Kurikulum dan Pembelajaran.Jakarta : Bumi Aksara

Purwanto. 2016. Evaluasi Hasil Belajar. Surakarta: Pustaka Belajar

Sardiman. 2016. Interaksi \& Motivasi Belajar Mengajar. Jakarta: PT. Raja Grafindo Persada.

Ahmad,Sabri, . 2010. Strategi Belajar Mengajar. Padang: Quantum Teaching.

Slameto. 2015. Belajar dan FaktorFaktor Yang Mempengaruhi, Jakarta:Rineka Cipta.

Sudjana . 2017. Metoda Statistika. Bandung: PT. Tarsito.

Sugiyono. 2016. Metode Penelitian Kuantitatif, Kualitatif, dan $R \& D$. Bandung: Alfabeta, CV. - 2017Metode Penelitian Kuantitatif, Kualitatif, dan $R \& D$. Bandung: Alfabeta, CV.

Susanto, Ahmad. 2013. Teori Belajar \& Pembelajaran di Sekolah Dasar. Jakarta: Kencana.

2016. Teori Belajar \& Pembelajaran di Sekolah Dasar. Jakarta: Kencana.

Trianto.2011. Mendesain Model Pembelajaran Inovatifprogresif. Jakarta: Kencana.

Widi Wisudawati, Asih dan Eka Sulistyowati. 2015. Metodologi Pembelajaran IPA. Jakarta: Bumi Aksara

http://alifaku.blogspot.com/2009/11/strate gi-pembelajaran-variasigaya.html 